\title{
PEMANFAATAN BIOPESTISIDA RAMAH LINGKUNGAN TERHADAP HAMA Leptocorisa acuta TANAMAN PADI SAWAH
}

\section{UTILIZATION OF ENVIRONMENTAL FRIENDLY BIOPESTICIDE AGAINST Leptocorisa acuta OF RICE PLANT PEST}

\author{
Christina L. Salaki dan Jantje Pelealu*) \\ *) Jurusan Hama dan Penyakit Tumbuhan Fakultas Pertanian Unsrat Manado dan Program Pascasarjana Unsrat \\ Manado, Jl. Kampus Unsrat, Bahu, 95115, Email : christinasalaki@ymail.com
}

\begin{abstract}
The research was conducted in the centre production area of rice plants which on North Minahasa District and laboratory tests conducted in Entomology and Plant Pests Laboratory on Pest and Disease Plant course of Sam Ratulangi University, Manado. This research took one year of research period. The results of testing the power to kill isolates of entomopathogenic fungal isolates obtained the highest is MMTTO which had ability to kill nymphs of Leptocorisa acuta (93.3\%). Followed by MMITO isolates $(86.7 \%)$ and MMSAM (80.0\%). The isolates are isolates of the fungus Metarhizium anisopliae. Selection results isolates of $B$. bassiana in nymphs $L$. acuta which best is BEMSAM isolates (86.7\%) followed BEMTTO isolates $(83.3 \%)$. Then those isolates will be used for the manufacture of biopesticide. Pathogenicity test results showed that each of entomopathogenic fungi to insects $L$. acuta after 7 days of infection, average mortality ranged from 83.3 to $93.3 \%$ and was significantly different from controls. Isolates Metarhizium sp and Beauveria sp each takes a minimum of 22.4 hours and 29.5 hours to kill $50 \%$ of test insects.
\end{abstract}

Keywords : biopesticide, important pests, rice plant

\begin{abstract}
ABSTRAK
Penelitian ini dilaksanakan di sentra produksi tanaman padi yang ada di Kabupaten Minahasa Utara dan uji laboratorium dilaksanakan di Laboratorium Entomologi dan Hama Tumbuhan Jurusan Hama dan Penyakit Tumbuhan Fakultas Pertanian Universitas Sam Ratulangi, Manado. Penelitian dilaksanakan selama 1 tahun. Hasil pengujian daya bunuh isolat-isolat jamur entomopatogen didapatkan isolate MMTTO paling tinggi kemampuan membunuh nimfa Leptocorisa acuta $(93,3 \%)$. Kemudian diikuti dengan isolate MMITO $(86,7 \%)$ dan MMSAM $(80,0 \%)$. Isolat-isolat tersebut merupakan isolat dari cendawan Metarhizium anisopliae. Hasil seleksi isolat $B$. bassiana pada nimfa $L$. acuta adalah isolat terbaik BEMSAM $(86,7 \%)$ diikuti isolat BEMTTO $(83,3 \%)$. Maka isolat-isolat tersebutlah yang digunakan untuk pembuatan Bioinsektisida. Hasil uji patogenisitas menunjukkan bahwa masing-masing cendawan entomopatogen terhadap serangga $L$. acuta setelah 7 hari penginfeksian rata-rata mortalitasnya berkisar antara 83,3 - 93,3\% dan berbeda nyata dengan kontrol. Isolat Metarhizium sp dan Beauveria sp masing-masing membutuhkan waktu paling singkat 22,4 jam dan 29,5 jam untuk mematikan $50 \%$ serangga uji.

Kata kunci : biopestisida, hama penting, tanaman padi
\end{abstract}

Eugenia Volume 21 No. 3 Oktober 2015 


\section{PENDAHULUAN}

Beras merupakan bahan makanan pokok bagi penduduk Indonesia, karena sebagian besar masih mengkonsumsi sebagai sumber karbohidrat, sehingga beras menjadi komoditi strategis. Kekurangan persediaan beras dapat mengganggu kestabilan negara, juga dapat menimbulkan gejolak sosial. Aspek ekonomi persediaan beras dapat mengganggu laju inflasi. Oleh karena itu diperlukan suatu kesinambungan produksi secara terus menerus.

Adanya program peningkatan produksi, menyebabkan kenaikan produksi di beberapa daerah penghasil beras utama di Indonesia, seperti Jawa Barat, Jawa Tengah, Jawa Timur, Sumatera Selatan dan Sulawesi Selatan. Rata-rata kenaikan produksi untuk tiga tahun terakhir menjadi 3,78 \%, dengan produksi nasional mencapai 66,41 juta ton pada tahun 2010. Di Provinsi Sulawesi Utara, produksi padi meningkat dari tahun 2007-2012 (Tabel 1).

Berdasarkan Tabel 1, maka produktivitas tanaman padi di Sulawesi Utara rata-rata 48,2 ton per Ha. Kemudian rata-rata produktivitas Nasional (tahun 2007-2012) adalah 49.52 ton per Ha, maka di Sulawesi Utara tergolong masih rendah. Rendahnya produksi padi di Sulawesi Utara disebabkan oleh (a) petani pada umumnya tidak menanam benih padi bermutu dan bersertifikasi, (b) sistem budidaya tanaman belum optimal, (c) adanya serangan hama dan penyakit. Serangan hama pada tanaman padi relatif tinggi setiap tahun. Serangan tersebut belum dapat dikendalikan secara optimal, sehingga mengakibatkan kerugian yang cukup besar baik kehilangan hasil, menurunnya mutu, terganggunya kontunitas produksi, serta menurunnya pendapatan petani.

Ketersediaan beras untuk kebutuhan umat manusia tergantung pada produksi yang dihasilkan oleh padi sawah tersebut. Banyak faktor yang mempengaruhi terhadap pertumbuhan dan perkembangan tanaman padi sawah sampai panen diantaranya hama dan penyakit tanaman. Diketahui sekitar 22 spesies hama yang menyerang tanaman padi sawah di Sulawesi Utara, termasuk hama Leptocorisa acuta yang menyebar pada pertanaman padi.

Hama ini adalah hama yang umum merusak bulir, pada fase pemasakan. Cara merusaknya yaitu mengisap butiran gabah yang sedang mengisi. Bila diganggu, serangga mempetahankan diri dengan mengeluarkan bau. Selain sebagai cara pertahanan, juga sebagai sebagai sarana menarik walang sangit lain dari spesies yang sama. Walang sangit merusak tanaman ketika mencapai fase berbunga sampai matang susu. Akibat kerusakannya, beras berubah warna dan mengapur, serta gabah jadi hampa.

Berbagai usaha telah dilakukan untuk meningkatkan produksi tanaman padi antara lain secara intensifikasi maupun ekstensifikasi. Dalam usaha meningkatkan produksi padi tentu tidak lepas dari faktor-faktor pembatas yang mempengaruhi kualitas dan kuantitas. Kerusakan tanaman akibat serangan hama tidak pernah berkurang, malahan semakin meningkat. Kerugian karena hama di Indonesia per tahun diperkirakan 15-20\% dari produksi pertanian total. Petani Sulut sudah terbiasa menggunakan pestisida dalam mengendalikan hama tanaman yang umumnya tidak lagi memperhatikan jenis hama pada waktu penyemprotan. Akibatnya petani cenderung menambah dosis pestisida yang dianjurkan dan interval waktu penyemprotan semakin pendek. Sebagai contoh, petani sayuran di Kecamatan Tompaso (sentra produksi hortikultura di Kabupaten Minahasa Selatan) dan Desa Rurukan (sentra produksi sayuran di Kota Tomohon) dan Desa Modoinding (sentra produksi sayuran) menyemprot sampai 10 kali dalam satu musim tanam. Adanya pengaruh buruk bagi lingkungan dan fenomena resistensi pada serangga hama akibat penggunaan insektisida telah meningkatkan perhatian para ahli terhadap penelitian tentang pemanfaatan patogen-patogen untuk mengendalikan hama-hama tanaman pertanian. Patogen serangga relatif bersifat spesifik dan pengaruhnya seandainya ada jauh lebih kecil dari pada yang ditimbulkan oleh bahan-bahan kimia terhadap lingkungan atau organisme bukan sasaran. 
Tabel 1. Luas Panen, Produksi, dan Produktivitas Tanaman Padi dari Tahun 2007-2012

(Table 1. Harvest Areas, Productions, and Productivities of Rice Plant from 2007-2012)

\begin{tabular}{cccc}
\hline Tahun & Luas Panen $(\mathrm{Ha})$ & Produksi (Ton) & Produktivitas (Ton/Ha) \\
\hline 2007 & 103189.00 & 49495.00 & 47.97 \\
2008 & 109951.00 & 520193.00 & 47.31 \\
2009 & 114745.00 & 549087.00 & 47.85 \\
2010 & 119771.00 & 584030.00 & 48.76 \\
2011 & 122108.00 & 596223.00 & 48.83 \\
2012 & 127729.00 & 619413.00 & 48.49
\end{tabular}

Sumber: Badan Pusat Statistik Nasional Online, 2012 (http://www.bps.go.id/tnmn_pgn.php?kat=3)

Penelitian mengenai isolasi strain bakteri dan jamur kini sedang dilaksanakan dalam upaya mendapatkan strain-strain yang dapat digunakan untuk mengendalikan larva nyamuk Anopheles, Culex dan Aedes. Dalam penelitian ini akan lebih menitikberatkan pada pencarian isolat-isolat lokal yang berasal dari beberapa kawasan yang patogen terhadap hama ordo Lepidoptera, Hemiptera dan Homoptera. Tujuan dari penelitian ini adalah untuk mengetahui tingkat patogenisitas isolat entomopatogenik pada serangga hama tanaman pangan (tanaman padi) dan mendapatkan isolat mikroba yang memiliki virulensi yang tinggi terhadap OPT tanaman padi untuk dijadikan sebagai kandidat biopestisida yang unggul.

\section{METODE PENELITIAN}

Penelitian ini dilaksanakan dalam beberapa tahap dengan lokasi sebagai berikut: 1) Isolasi jamur entomopatogenik dan uji daya bunuh dilaksanakan di Laboratorium Mikrobiologi dan Penyakit Tumbuhan Jurusan Hama dan Penyakit Tumbuhan Fakultas Pertanian UNSRAT; 2) Uji patogenisitas untuk mendapatkan nilai $\mathrm{LC}_{50}$ dan LC 90 dilaksanakan di Laboratorium Mikrobiologi dan Penyakit Tumbuhan Jurusan Hama dan Penyakit Tumbuhan Fakultas Pertanian UNSRAT; 3) Uji efikasi (demonstrasi plot) dilaksanakan pada sentra produksi tanaman padi di Minahasa Utara. Penelitian dilaksanakan selama 1 tahun.

\section{Persiapan Isolat dan Seleksi Isolat}

Isolasi jamur entomopatogenik dengan cara menangkap serangga yang terserang jamur entomopatogen dan yang diisolasi dari tanah. Jamur tersebut dimurnikan dan dibiakkan dalam media PDA untuk digunakan selanjutnya dalam uji daya bunuh dan patogenisitas terhadap serangga uji.

Serangga terserang $B$. bassiana dan Metarhizium sp. didapatkan dari berbagai lokasi di Minahasa. Jamur tersebut lalu diisolasi dan dimurnikan sehingga didapatkan 12 isolat $B$. bassiana dan lima isolat Metarhizium sp. Metode isolasi kedua jenis jamur tanah (soil borne) ini mengikuti metode Santoso, et. al. (2007). Seleksi isolat tersebut dilakukan dengan cara spora masing-masing isolat diperbanyak pada media SDA, lalu spora dipanen dan dibuat suspensi dengan kerapatan spora $10^{6}$. Spora dihitung kerapatannya dengan menggunakan metode Herlinda, et. al. (2006). Spora diinokulasikan secara topikal masing-masing isolat pada 10 ekor nimfa wereng instar ketiga sebanyak 10 $\mu$ l per nimfa seperti metode Herlinda, et. al. (2006). Isolat terbaik yang dicirikan LT50 terendah dan mortalitas tertinggi dari masing-masing $B$. bassiana dan Metarhizium. Satu isolat terbaik dari $B$. bassiana dan satu isolat terbaik Metarhizium.

\section{Perbanyakan Spora dan Perbanyakan Formulasi}

Perbanyakan spora $B$. bassiana dan Metarhizium masing-masing dilakukan pada media beras pecah yang dicampur dengan EKKU 20\% dan air steril 30\% per $250 \mathrm{~g}$ media seperti pada kegiatan perbanyakan spora pada media jagung. Biakan B. bassiana (diberi kode A) dan Metarhizium (diberi kode $D$ ) masing-masing dicampur dengan larutan EKKU yang sebelumnya dipanaskan pada oven bersuhu $60^{\circ} \mathrm{C}$ selama dua jam. EKKU dituangkan ke dalam biakan tadi sedemikian rupa banyaknya hingga didapatkan kerapatan spora mencapai $109 \mathrm{spora} / \mathrm{ml}$, lalu campuran media jagung, EKKU dan jamur ini diblender, kemudian di- 
saring dengan saringan berdiameter $1 \mathrm{~mm}$. Formulasi cair ini lalu dimasukkan ke dalam botol gelas bening tahan panas (diameter $5 \mathrm{~cm}$, bervolume 500 $\mathrm{ml}$ ) yang steril, lalu ditutup dengan aluminium foil dan siap diaplikasikan atau disimpan. Untuk penyebutan berikutnya formulasi ini sebagai bioinsektisida formulasi $C$ untuk yang berbahan aktif $B$. bassiana, sedangkan formulasi $D$ untuk yang berbahan aktif Metarhizium.

\section{Persiapan Serangga Uji}

Imago dan nimfa walang sangit dan kepinding tanah dikumpulkan dari pertanaman padi di berbagai sentra produksi padi, seperti di Tondano, Langowan dan pertanaman padi di Kabupaten Minahasa. Kemudian nimfa dibawa ke laboratorium dan dipelihara dalam kurungan kasa $(30 \mathrm{~cm} \times 30$ $\mathrm{cm} \times 100 \mathrm{~cm}$ ). Dalam kurungan tadi dimasukkan tanaman padi fase vegetatif untuk pakan dan tempat peneluran walang sangit dan kepinding tanah. Setiap hari nimfa instar ke-3 yang terbentuk dipindahkan ke dalam kurungan plastik $(30 \mathrm{~cm} \times 50 \mathrm{~cm} \times 50$ $\mathrm{cm}$ ) yang berisi pakan baru dan segar dan dipelihara di laboratorium. Nimfa walang sangit dan kepinding tanah yang digunakan untuk uji bioefikasi adalah keturunan kedua (F2) atau setelahnya.

\section{Uji Hayati Formulasi Jamur Biopestisida terhadap Serangga Uji}

Formulasi cair bioinsektisida diuji keefektifan pada tiga tingkat konsentrasi, yaitu 103 $10^{3}, 10^{7}$ spora/ml dan kontrol (air steril). Uji hayati ini dilakukan dengan cara meneteskan $10 \mu$ bionsektisida tadi pada kerapatan spora berbeda $10^{3} \mathrm{spora} / \mathrm{ml}$ secara topikal pada walang sangit dan kepinding tanah instar ketiga. Setiap perlakuan diaplikasikan pada 10 nimfa uji dan diulang sebanyak tiga kali. Cara yang sama juga dilakukan pada bioinsektida lainnya dengan masing-masing konsentrasi $10^{5}$ dan $10^{7} \mathrm{spora} / \mathrm{ml}$, dan kontrol. Nimfa walang sangit dan kepinding tanah instar ketiga yang telah diaplikasikan formulasi bioinsektisida selanjutnya dipelihara dalam silinder plastik (diameter $8,5 \mathrm{~cm}$ dan tinggi $15 \mathrm{~cm}$ ) yang ditutup kain kasa dan di dalamnya terdapat setangkai buah padi yang matang susu. Setiap 3 jam selama fase nimfa dicatat jumlah nimfa yang mati, sedangkan jumlah nimfa yang ter- sisa yang membentuk imago dicatat setiap hari hingga semua nimfa menjadi imago.

\section{Analisis Data}

Data mortalitas dan waktu kematian nimfa wereng dianalisis menggunakan LT50 (Lethal Time) dengan menggunakan analisis probit dengan bantuan program SPSS ver. 18.

\section{HASIL DAN PEMBAHASAN}

\section{Isolasi Jamur Entomopatogenik}

Hasil isolasi jamur entomopatogenik yaitu adanya pertumbuhan miselium jamur pada kutikel serangga.

Lama-kelamaan pertumbuhan miselium ini membungkus seluruh permukaan tubuh dan miselium-miseliumnya menembusi bagian internal tubuh serangga. Pertumbuhan miselium diikuti dengan perkembangan spora atau konidia jamur yang menjadi alat infeksi jamur terhadap serangga inang yang lain. Serangga yang terinfeksi berwarna putih (Beauveria bassiana) dan putih kehijauan (Metarhizium anisopliae).

\section{Uji Daya Bunuh Jamur Entomopatogenik Perbanyakan Serangga Uji} Imago dan nimfa serangga uji dikumpulkan dari pertanaman padi di berbagai sentra produksi padi, seperti di Tondano, Langowan dan pertanaman padi di Kabupaten Minahasa. Kemudian nimfa dibawa ke laboratorium dan dipelihara dalam kurungan kasa $(30 \mathrm{~cm} \times 30 \mathrm{~cm} \times 100 \mathrm{~cm})$. Dalam kurungan tadi dimasukkan tanaman padi fase vegetatif untuk pakan dan tempat peneluran walang sangit dan kepinding tanah. Setiap hari nimfa instar ke-3 yang terbentuk dipindahkan ke dalam kurungan plastik $(30 \mathrm{~cm} \times 50 \mathrm{~cm} \times 50 \mathrm{~cm}$ ) yang berisi pakan baru dan segar dan dipelihara di laboratorium. Nimfa walang sangit dan kepinding tanah yang digunakan untuk uji bioefikasi adalah keturunan kedua (F2) atau setelahnya.

\section{Uji Daya Bunuh}

Isolat-isolat cendawan entomopatogen diinokulasikan secara topikal dengan konsentrasi spora $10^{7}$ pada nimfa walang sangit (Leptocoriza acuta). 

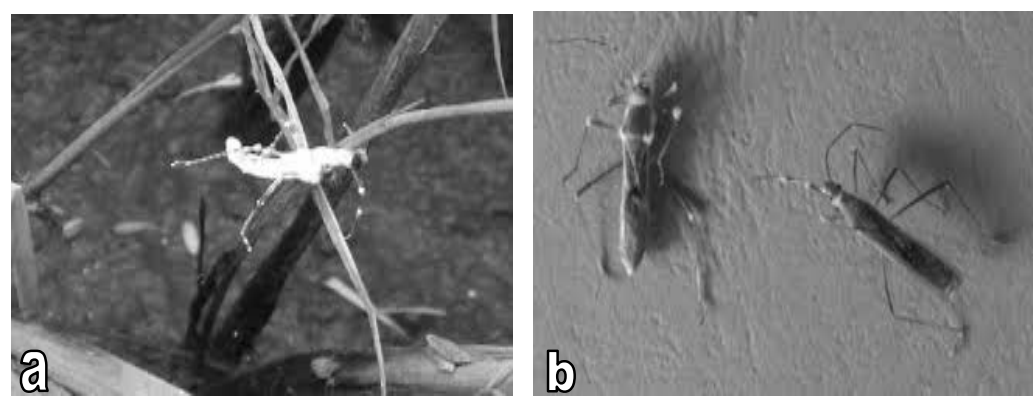

Gambar 1. a) Leptocorisa acuta yang Terinfeksi Metarhizium anisopliae

b) Leptocorisa acuta yang Terinfeksi dan yang Sehat

(Figure 1. a) Leptocorisa acuta Which was Infected by Metarhizium anisopliae

b) Leptocorisa acuta Which Infected and the Healthy One)

Tabel 2. Uji Daya Bunuh Isolat-isolat Jamur Entomopatogen terhadap Serangga Uji Nimfa Leptocorisa acuta

(Table 2. Screening Tests of Mortality of Entomopathogenical Fungi Isolates Against Test Insects Leptocorisa acuta nymphs)

\begin{tabular}{cccc}
\hline Kode Isolat & Mortalitas $(\%)$ & Kode Isolat & Mortalitas $(\%)$ \\
\hline MMTTO & 93,3 & BEMTTO & 83,3 \\
MMTRA & 76,7 & BEMSAM & 86,7 \\
MMSAM & 80,0 & BEMSLO & 70 \\
MMSLO & 76,7 & BEMSTA & 60 \\
MMSTA & 63,3 & BEMITD & 63,3 \\
MMITD & 60 & BEMITO & 56,7 \\
MMITO & 86,7 & BEMUMB & 43,3 \\
MMUMP & 46,7 & & \\
MMUMB & 56,7 & & \\
MMLLY & 63,3 & & \\
\hline
\end{tabular}

Hasil pengujian daya bunuh isolat-isolat jamur entomopatogen didapatkan isolat MMTTO paling tinggi kemampuan membunuh nimfa Leptocorisa acuta $(93,3 \%)$. Kemudian diikuti dengan isolate MMITO $(86,7 \%)$ dan MMSAM $(80,0 \%)$. Isolat-isolat tersebut merupakan isolat dari cendawan Metarhizium anisopliae. Hasil seleksi isolat $B$. bassiana pada nimfa $L$. acuta adalah isolat terbaik BEMSAM $(86,7 \%)$ diikuti isolat BEMTTO $(83,3 \%)$. Isolat-isolat tersebut yang digunakan untuk pembuatan bioinsektisida.

Penentuan isolat MMTTO, MMITO dan MMSAM dari cendawan Metarhizium dan isolat BEMSAM, BEMITO dari cendawan Beauveria merupakan isolat terbaik didasarkan atas kemampuan kelima isolat ini tertinggi dalam mematikan nimfa $L$. acuta. Hal ini mengindikasikan bahwa semua cendawan entomopatogen yang diuji pada penelitian dalam skala laboratorium sangat efektif sebagai agen pengendali hama $L$. acuta.

Tingginya rata-rata mortalitas $L$. acuta setelah penginfeksian oleh cendawan entomopatogen disebabkan oleh sifat fisiologis dari masing-masing cendawan itu sendiri yang rata-rata baik. Metabolisme sekunder yang dihasilkan yaitu kemampuan menghasilkan enzim dan toksin serta tidak adanya faktor penghambat baik dari serangga inang maupun pengaruh faktor lingkungan. Menurut Noveriza (2007), tingkat mortalitas setelah aplikasi cendawan entomopatogen juga tergantung pada berbagai karakteristik dari potensi serangga inang dan lingkungan sekelilingnya.

Pada penelitian ini, serangga inang yang mati terinfeksi $B$. bassiana menunjukkan gejala tidak mau makan, pergerakan lambat, lalu mati kaku. Setelah mati dari tubuh walang yang kaku 
dan kering tadi muncul hifa jamur berwarna putih. Serangga inang yang mati terinfeksi Metarhizium sp. menunjukkan gejala mirip dengan terinfeksi $B$. bassiana tetapi hifanya berwarna putih kehijauan, sedangkan hifa $B$. bassiana berwarna putih.

Selama proses inokulasi spora isolat jamur kelembaban di dalam sungkup serangga inang di atas $90 \%$ dan suhu ruangan diatur agar berkisar $23-25^{\circ} \mathrm{C}$. Hal ini dilakukan untuk mencegah kegagalan spora berkecambah. Bidochka, et. al. (2000) menyatakan untuk perkecambahan spora jamur entomopatogen membutuhkan suhu optimum berkisar $22-27^{\circ} \mathrm{C}$, sedangkan kelembaban optimum di atas $90 \%$ dan pada kelembaban yang semakin tinggi jamur semakin virulens. Virulensi jamur ini akan semakin menurun dengan semakin menurunnya kelembaban udara. Pada kelembaban udara yang lebih rendah dari $86 \%$, virulensi jamur akan terus menurun.

Jamur entomopatogen ini membutuhkan waktu untuk mematikan serangga inangnya. Hal ini disebabkan konidia jamur yang menempel pada kutikula harus berkecambah membentuk hifa terlebih dahulu agar dapat menembus kutikula. Hifa mengeluarkan enzim-enzim kitinase dan protease yang dapat menghancurkan kutikula pada integumen. Selanjutnya, hifa masuk ke dalam tubuh inang (Wahyudi, 2002). Di dalam rongga tubuh inang, jamur menghasilkan beauvericin dan bassianolid yang dapat melemahkan sistem kekebalan tubuh inang (Hajek and Leger, 1994).

\section{Uji Patogenisitas Isolat Jamur Entomopatogen}

Hasil uji patogenisitas menunjukkan bahwa jenis cendawan tidak berpengaruh nyata ter- hadap mortalitas nimfa Leptocorisa acuta. Untuk mengetahui tingkat mortalitas nimfa $L$. acuta akibat infeksi cendawan entomopatogen dapat dilihat pada Tabel 3.

Hasil uji patogenisitas menunjukkan bahwa masing-masing cendawan entomopatogen terhadap serangga $L$. acuta setelah 7 hari penginfeksian rata-rata mortalitasnya berkisar antara 83,3-93,3 \% dan berbeda nyata dengan kontrol.

Cendawan Metarhizium (isolat MMITO, MMTTO, dan MMSAM) dan Beauveria (isolat BEMSAM dan BEMTTO) merupakan cendawan yang memiliki patogenisitas paling tinggi. Cendawan Metarhizium pada penelitian ini diisolasi dari serangga yang terinfeksi dan terbukti mampu mematikan L. acuta. Metarhizium (isolat MMITO, MMTTO, dan MMSAM) tingkat patogenisitasnya sangat tinggi rata-rata diatas 83,3\% (Tabel 2). Karakteristik cendawan seperti ini mengindikasikan bahwa Metarhizium memiliki virulensi yang sangat tinggi dan dapat dijadikan kandidat agen hayati dalam mengendalikan $L$. acuta di tingkat lapangan.

Kemampuan entomopatogenesitas Metarhizium dikarenakan cendawan ini memiliki aktivitas larvisidal dan mampu memproduksi cyclopeptida, destrtuxin A, B, C, D, E dan desmethyldestruxin B. Destruxin jenis ini telah dipertimbangkan sebagai bahan insektisida generasi baru (Anonymous, 2007). Efek destruxin berpengaruh pada organela sel target (mitokondria, reticulum, endoplasma dan membran nukleus) menyebabkan paralisa sel dan kelainan fungsi lambung tengah, tubulus malphigi, hemocyt dan jaringan otot (Widiyanti dan Mulyadihardja, 2004).

Tabel 3. Uji Patogenisitas Isolat-isolat Jamur Entomopatogen terhadap Serangga Uji Nimfa Leptocorisa acuta

(Table 3. Pathogenicity Tests of Entomopathogenical Fungi Isolates Against Test Insects Leptocorisa acuta Nymphs)

\begin{tabular}{|c|c|c|c|c|c|c|c|}
\hline \multirow{2}{*}{ Kode Isolat } & \multirow{2}{*}{ Mortalitas (\%) } & \multicolumn{3}{|c|}{$\mathrm{LC}_{50}$ (spora/ml) } & \multicolumn{3}{|c|}{$\mathrm{LT}_{50}$ (jam) } \\
\hline & & & BB & $\mathrm{BA}$ & & $\mathrm{BB}$ & BA \\
\hline MMTTO & 86,7 & $6,3 \times 10^{4}$ & $3,3 \times 10^{4}$ & $1,02 \times 10^{5}$ & 22,4 & 17,4 & 28,8 \\
\hline MMITO & 93,3 & $1,9 \times 10^{4}$ & $4,1 \times 10^{3}$ & $7,7 \times 10^{4}$ & 24,6 & 18,6 & 32,4 \\
\hline MMSAM & 83,3 & $1,02 \times 10^{5}$ & $5,9 \times 10^{4}$ & $1,7 \times 10^{5}$ & 28,2 & 23,4 & 36,2 \\
\hline BEMSAM & 86,7 & $2,9 \times 10^{4}$ & $2,3 \times 10^{4}$ & $9,7 \times 10^{4}$ & 29,5 & 23,9 & 36,0 \\
\hline BEMTTO & 83,3 & $2,5 \times 105$ & $1,1 \times 10^{5}$ & $5,8 \times 10^{5}$ & 30,9 & 19,1 & 38,02 \\
\hline Kontrol & 33,3 & & & & & & \\
\hline
\end{tabular}


Cendawan Beauveria sebagai cendawan yang diuji patogenisitasnya pada penelitian ini diisolasi dari serangga yang terinfeksi. Cepatnya kematian $L$. acuta akibat infeksi cendawan Beauveria diduga disebabkan oleh toksin yang diproduksinya. Beauveria memproduksi toksin yang disebut beauvericin (Kucera, 1971). Selain itu, dilaporkan juga oleh Quesada-Vey (1998) cit Soetopo dan Indrayani (2007) bahwa Beauveria juga memproduksi senyawa metabolit skunder seperti bassianin, bassiacridin, bassianolide, beauverolides, tenellin dan ceosporein.

Isolat Metarhizium sp dan Beauveria sp masing-masing membutuhkan waktu paling singkat 22,4 jam dan 29,5 jam untuk mematikan 50\% serangga uji. Cukup lamanya waktu bagi spora jamur untuk mematikan inangnya karena spora yang menempel pada integumen inang harus berkecambah terlebih dahulu. Prayogo, et. al. (2005) menyatakan hifa dari spora Metarhizium sp. masuk ke rongga dalam tubuh inang karena bantuan enzim dan tekanan mekanik. Akhirnya seluruh tubuh serangga inang penuh dengan propagul dan bagian yang lunak dari tubuhnya akan ditembus keluar dan menampakan partumbuhan hifa di luar tubuh serangga inang. Pertumbuhan hifa eksternal akan menghasilkan konidia yang apabila telah masak akan disebarkan ke lingkungan dan menginfeksi serangga hama yang sehat.

Serangga inang yang mati terinfeksi $B$. bassiana menunjukkan gejala tidak mau makan, pergerakan lambat, lalu mati kaku. Setelah mati dari tubuh $L$. acuta yang kaku dan kering tadi muncul hifa jamur berwarna putih. Serangga inang yang mati terinfeksi Metarhizium sp. menunjukkan gejala mirip dengan terinfeksi $B$. bassiana tetapi hifanya berwarna putih kehijauan, sedangkan hifa B. bassiana berwarna putih.

Pada penelitian ini, selama proses inokulasi spora isolat jamur kelembaban di dalam sungkup serangga inang di atas $90 \%$ dan suhu ruangan diatur agar berkisar $23-25{ }^{\circ} \mathrm{C}$. Hal ini dilakukan untuk mencegah kegagalan spora berkecambah. Bidochka, et. al. (2000) menyatakan untuk perkecambahan spora jamur entomopatogen membutuhkan suhu optimum berkisar $22-27^{\circ} \mathrm{C}$, sedangkan kelembaban optimum di atas $90 \%$ dan pada kelembaban yang semakin tinggi jamur semakin virulens. Virulensi jamur ini akan semakin menurun dengan semakin menurunnya kelembaban udara. Pada kelembaban udara yang lebih rendah dari $86 \%$, virulensi jamur akan terus menurun.

\section{KESIMPULAN}

Hasil pengujian daya bunuh isolat-isolat jamur entomopatogen didapatkan isolat MMTTO paling tinggi kemampuan membunuh nimfa Leptocorisa acuta $(93,3 \%)$. Kemudian diikuti dengan isolat MMITO $(86,7 \%)$ dan MMSAM $(80,0 \%)$. Isolat-isolat tersebut merupakan isolat dari cendawan Metarhizium anisopliae. Hasil seleksi isolat $B$. bassiana pada nimfa $L$. acuta adalah isolat terbaik BEMSAM (86,7\%) diikuti isolat BEMTTO (83,3\%). Isolat-isolat tersebut yang digunakan untuk pembuatan bioinsektisida.

Hasil uji patogenisitas menunjukkan bahwa jenis cendawan tidak berpengaruh nyata terhadap mortalitas nimfa Leptocorisa acuta.

Hasil uji patogenisitas menunjukkan bahwa masing-masing cendawan entomopatogen terhadap serangga $L$. acuta setelah 7 hari penginfeksian rata-rata mortalitasnya berkisar antara 83,393,3\% dan berbeda nyata dengan kontrol.

Isolat Metarhizium sp dan Beauveria sp masing-masing membutuhkan waktu paling singkat 22,4 jam dan 29,5 jam untuk mematikan 50\% serangga uji.

\section{DAFTAR PUSTAKA}

Anonymous. 2007. Karakteristik cendawan Metarhizium anisopliae dan mekanisme infeksi. http://pangerancakeb.wordpress. com. Artikel Metarhizium (28 Januari 2009).

Bidochka, M.J., A.M. Kamp and J.N.A. Decroos. 2000. Insect Pathogenic Fungi: From Genes to Populations. Fungal Pathol. 42:171-193. 
Hajek, A.E. and R.J.S. Leger. 1994. Interaction Between Fungal Pathogenic and Insect Host. Ann. Rev. Entomol. 39:293-322.

Herlinda, S., T. Hamadiyah. Adam dan R. Thalib. 2006. Toksisitas Isolat-isolat Beauveria bassiana (Bals.) Vuill. Terhadap Nimfa Eurydema pulchrum (Westw.) (Hemiptera: Pentatomidae). Agria 2:34-37.

Kuecera, M. 1971. Toxin of the Entomophagous Fungus Beauveria bassiana; Effect of Nitrogen Sources on Formation on the Toxic Protease In Submerged Culture. J.Invertebr. Pathol (17): 211-215.

Noveriza, R. 2007. Kontaminasi Cendawan dan Mikotoksin pada Tumbuhan Obat. Balai Penelitian Tanaman Obat dan Aromatika. Bogor.

Prayogo, Y., W. Tengkono, Marwoto. 2005. Prospek Cendawan Entomopatogen Metarhizium anisopliae untuk Mengendalikan Ulat Grayak Spodoptera litura pada Kedelai. Jurnal Litbang Pertanian 24 (1): 19-26.
Santoso, S.E., L. Soesanto dan T.A.D. Haryanto. 2007. Penekanan Hayati Penyakit Moler pada Bawang Merah dengan Trichoderma harzianum, Trichoderma koningii, dan Pseudomonas flourescens. p60. J HPTT. 7:53-61.

Soetopo, D. dan I. Indrayani. 2007. Status Teknologi dan Prospek Beauveria bassiana untuk Pengendalian Serangga Hama Tanaman Perkebunan yang Ramah Lingkungan. Balai Penelitian Tanaman Tembakau dan Serat. Malang.

Wahyudi, P. 2002. Uji Patogenitas Kapang Entomopatogen Beauveria bassiana Vuill. terhadap Ulat Grayak (Spodoptera litura). Biosfera 19:1-5.

Widiyanti, N. L. P., Mulyadihardja. 2004. Uji Toksisitas Jamur Metarhizium anisopliae terhadap Larva Nyamuk Aedes aegypti. Media Libang Kesehatan XIV (3). 